\title{
Etikk og estetikk ved prehospital torakotomi
}

\author{
Siden den prehospitale luftambulansetjenesten er offentlig finansiert, er det av allmenn interesse hvordan \\ den er organisert og hvordan midlene blir prioritert. Ved introduksjon av nye prehospitale metoder av eks- \\ perimentell natur bør man stille samme krav til kunnskapsgrunnlag og samfunnsnytte som man gjør i andre \\ deler av klinisk medisin.
}

Innen traumebehandlingen er det gjerne ytterlighetene som tiltrekker seg oppmerksomhet. Indikasjon og nytte av nødtorakotomi, hvor brysthulen åpnes for å stanse blødning eller avlaste hjertetamponade hos pasienter med traumatisk hjertestans, er hyppig debattert. Sannsynligvis forekommer det publiseringsskjevhet, gitt den store variasjonen studiene imellom (1). Det er også sprik mellom retningslinjer og klinisk praksis (2).

Ottestad og medarbeidere (3) argumenterer i Tidsskriftet nr. 23-24/2016 for at prehospital resuscitativ torakotomi bør ha en plass i en avansert prehospital legetjeneste i Norge. Prehospitale tall er begrenset, og i utgangspunktet er de basert på erfaringer rapportert fra de prehospitale legetjenestene i London (4), som er kjent for en svært liberal tilnærming til flere prosedyrer som ellers helst kun utføres i sykehus (5).

Det ligger en skjevhet $i$ at der tilgjengelighet eller kultur gjør at man utfører prosedyren oftere og med liberal indikasjon, vil resultatene kunne bli påvirket av dette. Suksessraten vil derfor variere med antall utførte torakotomier og holdning til og indikasjon for å gjøre inngrepet, og både overog underbehandling kan forekomme (6).

Man kan ikke se bort fra at inngrepet også kan være skadelig. I en stor studie med barn med traumatisk hjertestans prehospitalt (uten tegn til liv) var det likevel en andel som overlevde, men det gikk dårligst for dem der det ble utført resuscitativ torako-

«Selv i de tetteste

urbane strøk i Norge If.eks. Oslo og Stavangerl er befolkningstetthet, skadeforekomst og andelen stikk-og skuddskader betydelig annerledes enn i London»

tomi ved ankomst sykehus (7). Det er også vist at ved nødtorakotomier utført i sykehus er resultatene dårligere når prosedyren utføres av andre enn kirurger (8).

De geografiske forhold og befolkningstettheten i London er veldig forskjellig fra dem vi kjenner fra Norge (fig 1). Man kan undres over hvorfor rapporter tilsvarende den fra London (4) ikke foreligger fra andre store urbane områder i Europa.

I en studie fra Berlin om årsaker til og feilvurderinger ved traumatisk hjertestans hadde 19 av 20 pasienter med ustabil bekkenfraktur ikke fått adekvat stabilisering prehospitalt (9), og tre av fire behandlingsfeil ble gjort før pasienten kom til sykehus. Det forelå flere dødsfall med uavlastet trykkpneumothorax - for disse er bilaterale thoraxdren førstevalg etter gjeldende retningslinjer (10), og muslingtorakotomi bør ikke brukes som indikasjon for trykkpneumothorax. I samme materiale var det fem tilfeller av hjertetamponade som potensielt kunne vært reddet med intervensjon, men tid fra skade til hjertestans og tilstedeværelse av lege var ikke dokumentert, slik at det er vanskelig å si noe om alle disse fem ville vært kandidater for prehospital torakotomi (9).

Selv i tettbefolkede Berlin er således andelen kandidater for prehospital torakotomi lav. Andre prehospitale prosedyrer med forbedringspotensial og dokumentert effekt bør prioriteres før man bruker ressurser på områder med marginal effekt.

Selv i de tetteste urbane strøk i Norge (f.eks. Oslo og Stavanger) er befolkningstetthet, skadeforekomst og andelen stikkog skuddskader betydelig annerledes enn
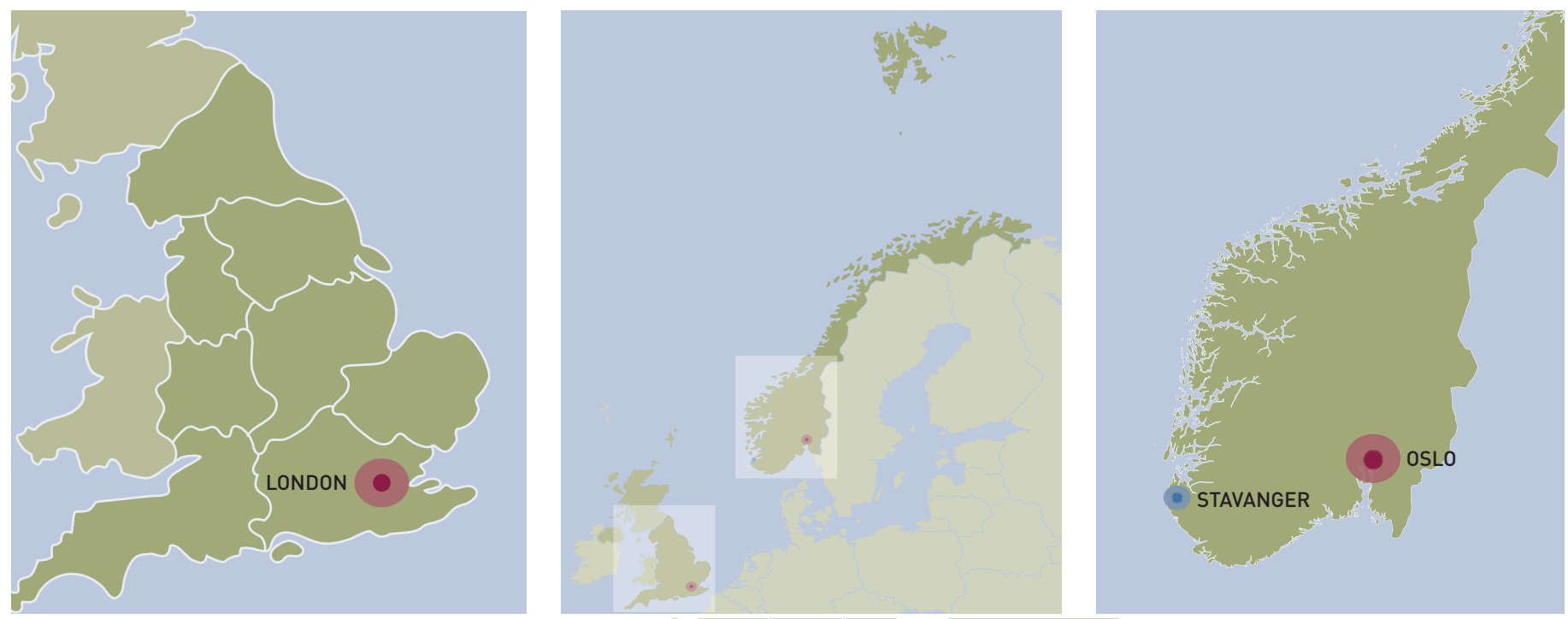

Figur 1 Estimater for geografisk utbredelse og befolkningstetthet i London, Oslo og Stavanger. London (urbane del): ca. $1740 \mathrm{~km}^{2}$, ca. 10 millioner innbyggere, befolkningstetthet ca. 5 220/km². Norge: ca. $385000 \mathrm{~km}^{2}$, ca. 5,2 millioner innbyggere, befolkningstetthet ca. 15/km². Stor-Oslo: ca. $8900 \mathrm{~km} \mathrm{~m}^{2}$, ca. 1,5 millioner innbyggere, befolkningstetthet ca. 160/km². Oslo: ca. $455 \mathrm{~km}^{2}$, ca. 660000 innbyggere, befolkningstetthet ca. 1 400/km². Stor-Stavanger: ca. $2600 \mathrm{~km}$, ca. 320000 innbyggere, befolkningstetthet ca. 120/km². Stavanger: ca. $71 \mathrm{~km}^{2}$, ca. 135000 innbyggere, befolkningstetthet ca. $1800 / \mathrm{km}^{2}$ 
i London (fig 1). Prosedyren gjelder utelukkende penetrerende skader, som nå utgjør rundt $20 \%$ av alle traumer i London-regionen (11) - noe som dermed ekskluderer ca. $95 \%$ av alle traumer i Norge. Selv om sjeldenhet i seg selv ikke trenger å være en motforestilling, vil de nødvendige ressursene for å sannsynliggjøre suksess være knyttet til prioritering. Hvor mange pasienter med torakale stikkskader døde prehospitalt og kunne vært reddet av legetjenestens prehospitale torakotomi gitt at omtrent 120 leger var sertifisert i denne prosedyren? Eksisterende data fra Oslo, Tromsø og Stavanger antyder at dette er ekstremt få.

Det er mange og dels betydelige diagnostiske og behandlingsmessige utfordringer i prehospital legetjeneste selv når det gjelder de vanligste skadetypene (hodeskader, bekkenskader og bukskader). Det største antall liv og den potensielt største helsetjenestegevinsten er å hente ved å rette oppmerksomheten mot diagnostikk og behandling nettopp der hvor manglene er størst. Da vil den legebemannede prehospitale tjenesten være samfunnsnyttig og livreddende og forsvare bruken av offentlige midler. Eksperimentelle metoder bør uansett ikke innføres uten at de implementeres i en etisk godkjent studie.

\section{Kjetil Søreide}

ksoreide@mac.com

Morten Vetrhus

Clemens Webe
Kjetil Søreide (f. 1977) er ph.d., spesialist i generell kirurgi og i gastroenterologisk kirurgi, overlege ved Gastrokirurgisk avdeling, Stavanger universitetssjukehus, og professor II ved Klinisk institutt 1, Universitetet i Bergen.

Forfatter har fylt ut ICMJE-skjemaet og oppgir ingen interessekonflikter.

Morten Vetrhus (f. 1968) er dr.med., spesialist i generell kirurgi og i karkirurgi og overlege ved Karkirurgisk seksjon, Kirurgisk avdeling, Stavanger universitetssjukehus.

Forfatter har fylt ut ICMJE-skjemaet og oppgir ingen interessekonflikter.

Clemens Weber (f. 1979) er ph.d., spesialist i nevrokirurgi og overlege ved Nevrokirurgisk avdeling. Stavanger universitetssjukehus. Forfatter har fylt ut ICMJE-skjemaet og oppgir ingen interessekonflikter.

\section{Litteratur}

1. Narvestad JK, Meskinfamfard M, Søreide K. Emergency resuscitative thoracotomy performed in European civilian trauma patients with blunt or penetrating injuries: a systematic review. Eur J Trauma Emerg Surg 2016; 42: 677-85.

2. Dennis BM, Medvecz AJ, Gunter OL et al. Survey of trauma surgeon practice of emergency department thoracotomy. Am J Surg 2016; 212: 440-5.

3. Ottestad W, Bredmose PB, Berve PO et al. Prehospital torakotomi ved traumatisk hjertestans. Tidsskr Nor Legeforen 2016: 136: 1964-5.

4. Davies GE, Lockey DJ. Thirteen survivors of prehospital thoracotomy for penetrating trauma: a prehospital physician-performed resuscitation procedure that can yield good results. J Trauma 2011; 70: E75-8

5. Sadek S, Lockey DJ, Lendrum RA et al. Resuscitative endovascular balloon occlusion of the aorta (REBOA) in the pre-hospital setting: An additional resuscitation option for uncontrolled catastrophic haemorrhage. Resuscitation 2016; 107: 135-8.

6. Søreide K. A forensic inquiry into compliance to guidelines for emergency resuscitative thoracotomy in trauma: If the dead can't talk and the living won't tell, it is a story half told. Injury 2016; 47: 1016-8.

7. Duron V, Burke RV, Bliss D et al. Survival of pediatric blunt trauma patients presenting with no signs of life in the field. J Trauma Acute Care Surg 2014: 77: 422-6.

8. Capote A, Michael A, Almodovar J et al. Emergency department thoracotomy: too little, too much, or too late. Am Surg 2013; 79: 982-6.

9. Kleber C, Giesecke MT, Lindner T et al. Requirement for a structured algorithm in cardiac arrest following major trauma: epidemiology, management errors, and preventability of traumatic deaths in Berlin. Resuscitation 2014: 85: 405-10.

10. Truhlář A, Deakin CD, Soar J et al. European Resuscitation Council Guidelines for Resuscitation 2015: Section 4. Cardiac arrest in special circumstances. Resuscitation 2015; 95: 148-201.

11. Lockey DJ, Weaver AE, Davies GE. Practical translation of hemorrhage control techniques to the civilian trauma scene. Transfusion 2013; 53 lsuppl 1): $17 S-22 S$.

Mottatt 30.12. 2016, første revisjon innsendt 17.1. 2017, godkjent 23.1. 2017. Redaktør: Ketil Slagstad.

Publisert først på nett. 